Journal of Financial Economics 34 (1993) 231-250. North-Holland

\title{
The underpricing of initial public offerings and the partial adjustment phenomenon*
}

\author{
Kathleen Weiss Hanley \\ University of Michigan, Ann Arbor, MI 48109, USA
}

Received May 1991, fina! version received Januaĩy 1993

This paper documents that the relation of the finai offer price to the range of anticipated offer prices disclosed in the preliminary prospectus is a good predictor of initia! returns. Issues that have final offer prices which exceed the limits of the offer range have greater underpricing than all other initial public offerings, and are also more likely to increase the number of shares issued. These results are consistent with the pricing and allocation schedule proposed by Benveniste and Spindi (1989), in which shares in an offering are rationed and prices only partially adjust to new information.

Key words: IPOs; Partial adjustment; Underpricing

\section{Introduction}

The empirical anomaly of positive average initial returns on invesiments in initial public offerings (IPOs) has been well documented. ${ }^{1}$ While many studies have researched the underpricing phenomenon, few have examined the process whereby the offer price is set. This study investigates how information-gathering activities by underwriters during the pre-issue period affect the final offer price, the size of the issue, and the subsequent level of initial returns.

Microsoft's initial public offering in March 1986 is an example of how information gathered prior to the IPO date affects the setting of the final offer

Correspondence to: Kathleen Weiss Hanley, School of Business Administration, University of Michigan, Ann Arbor, MI 48109-1234, USA.

*This paper is based on iny Ph.D. dissertation at the University of Clorica. i am grateful to Koger Huang (chairman), Roy Crum, and Roger Blaii of my dissertation committee fo: :is ir guidance and encouragement. Helpful comments from Susan Chaplinsky, Lariy Benveniste, Háry DeAngelo, Craig Dunbar, Jayant Kale, Naveen Khanna, Laura Kodres, Jonathan Paul, Jay Riti.'r, Cliff Smith (the editor), Bill Wilhelm, Gary Zeune, participants at the University of Michigan wo kshops, and an anonymous referee are appreciated. This paper was presented under the title 'The Reli tionship of Offer Price to the Preliminary File Range and the Use of the Overallotment Option in Ini ial Fubiic Offerings' at the 1990 Western Finance Association meetings.

${ }^{1}$ See Smith (1986) and Hanley and Ritter (1992) for a review of the IPO literature. 
price and, hence, the amount of underpricing. Initially, the firm and its underwriters filed a preliminary prospectus with the Securities and Exchange Commission (SEC) that indicated a range of minimum and maximum anticipated offer prices of $\$ 16$ to $\$ 19$. During the 'road show' for the Microsoft issue, Goldman Sachs' marketing group considered the offering 'very hot' and that "big institutional customers indicated they would take as much stock as they could get' [Uttal (1986. p. 28)]. Furthermore, 'the $\$ 16$ to $\$ 19$ price range would have to be raised ... and so would the number oi shares to be sold.' Consequently, the final uffer price was raised to $\$ 21$. The number of shares was also raised in the offering, as two shareholders were persuaded to sell an additional 295,000 shares (or $14.8 \%$ of the original issue amciunt). When Microsoft went public, the closing price on the first trading day was $\$ 27.75$, with a corresponding initial return of $32 \%$.

Consistent with the case of Microsoft, the results in this paper indicate that information gathered during the pre-issue period affects the pricing and allucation of initial public offerings. Issues that have positive revisions in the offer price, and are thus hypothesized to have favorable information revealed during the pre-issue period, show not only increases in the number of shares issued but also greater underpricing than other IPOs. Further, the relation of the final offer nrice to the range of anticipated offer prices disclosed in the preliminary prospectis is a good predictor of the amount of underpricing on the first trading day. For a sample of IPOs issued from 1983 to 1987, the mean initial return for firms going public at a price above the anticipated range is $20.7 \%$. Offerings that decrease the offer price to below the lowest anticipated price quoted in tine preliminary prospectus have an average initial return of $0.6 \%$, which is not significantly different from zero. The remaining issues, representing offerings within the anticipated range, have an average initial return of $10.0 \%$. The differences in initial returns among each of the three categories are significant at the $1 \%$ level. In addition, investors who purchase issues whose final offer price exceeds the anticipated range almost uniformly receive positive initial returns.

The high level of initial returns associated with issues with positive revisions in their final offer prices has been termed the 'partial adjustment' phenomenon by Ibbotson, Sindelar, and Ritter (1988). Instead of raising the final offer price to the market value of equity on the initial trading day, the underwriter (and the issuing firm) only partially adjust the price upwards. Why, then, does the surpius go to investors rather than to the issuing firm?

Benveniste and Spindt (1989) explain why prices only partially adjust to demand. They note that changes in the offer price between the filing of the preliminary prospectus and the offer date are a product of information gathered by underwriters from investors during the pre-issue period. When good information is revealed through high demand for the issue, the final offer price will exceed the expccted offer price. Alternatively, bad information is revealed by low demand and results in a decrease in the offer price to below the expected value. 
In their model, investors are motivated to truthfully reveai the level of demand through a pricing and allocation schedule that maximizes the investors' total expected profit. Investors who trutnfully reveal good information must expect greater profits than if they reveal bad information. Profits, in this case, are generated by a tradeoff between increased allocation and underpricing. [Sternberg (1989) independently documents this process and models the adjustment of offer prices to new information during the waiting period by a symmetric Nash bargaining solution between the underwriter and the issuer.]

The finding: of this study are consistent with a pricing and allocation schedule in which demand exceeds the available allocation. The results indicate that underwriters pre $\mathrm{er}$ to compensate investors for truthfully revealing information by allocating a sm aller number of highly-underpriced shares rather than a larger amount of slightly. underpriced shares.

Interestingly, alth sugh short-run returns are related to the relationship of the firal offer price to thi anticipated range of offer prices disclosed in the prelininary prospectus, the 'ong-run performance of IPOs cannot be explained by either revisions in the uffer price or the level of initial returns.

ine remainder of the paper is organized as follows. In section 2, the institutional aspects of the offering process and the model developed by Benveniste and Spindt are described. Section 3 presents the data, descriptive statistics, and the determinants of the final offer price, initial return, and number of shares offered. The long-run performance of the sample is examined in section 4 . The paper concludes with a brief summary in section 5 .

\section{The offering process}

After a company has decided to go public and has engaged an underwriter, it files a preliminary prospectus with the SEC that contains, among other things, the terms of the offering. In a firm commitment offering the anticipated offer price is stated in the form of an offer range, in which a minimum and maximum price are given; the expected offer price is the midpoint of this range. The setting of the offer range is prescribed by the SEC's Regulation S-K only in that it must be a 'bona fide estimate' of the final offer price."

The time from the filing of the preliminary prospectus to the final offer date is called the 'waiting period', during which the underwriter acquires information about the demand for the issue from regular investors through nonbinding indications of interest. Regular investors are those that are actively involved on an ongoing basis in purchasing shares of firms going public. If demand for the issue is greater than expected, the final offer price will be set higher than the

\footnotetext{
${ }^{2}$ Regulation S-K, Item 501(c)(6), 17C.F.R. 229.501

Fed. Sec. L. Rep. (CCH) 971,051 (October 21, 1987).
} 
expected offer price disclosed in the preliminary prospectus. Alternatively, if demiand is low, the final offer price will be below the expected offer pric In practice, changes in the offer price are accompanied by revisions in the number of shares being issued.

Benveniste and Spindt (1989) develop a model of the pricing and allocation rules that are used by underwriters of initial public offerings to induce regular investors to truthfully reveal information. In order for investors with good information to be motivated to reveal that information in the pre-issue period, these investors must expect to profit more by being truthful than by revealing false information. This expected profit consists of a tradeoff between the allocation of shares and the level of initial returns. For example, when dernand is high, the underwriter adjusts the offer price upward which, in turn, reduces the expected level of ur:derpricing. Truth-telling is induced, therefore, by giving the investor who acknowledges his or her goud inforination a larger portion of a smaller return. As long as the allocations increase at a rate greater than the rate at which returns decrease, the truth-iellers will be better off than the liars. ${ }^{3}$

An investor is deterred from revealing false information because doing so would jeopardize his or her expected allocation. In the model, underwriters give preference in allocating shares to investors who reveal good information. Therefore, when shares in the issue are rationed, an investor who falsely indicates bad information risks an economically injunious reduction in his or her allocition.

If shares of the issue are rationed, then underpricing musi also be usid to compensate investors for truthfully revealing good information. Benveniste and Spindt state (in their theorem 1) that, holding the level of pre-sales constant, underpricing will occur in states in which demand by investors indicating good information exceeds the number of shares to be pre-sold. In this case, 'underpricing is directly reiated io the level of interest in the pre-market'. An empirical prediction put forth by Benveniste and Spindt is that issues priced in the upper part of the offer range are likely to be more underpriced' (p. 353) than other IPOs. What this theorem suggests is that if the potential underpricing at the expected offer price is very large, a firm can increase its final offer price, thus reducing its own underpricing, yet still have higher underpricing than other firms with more accurate offer ranges.

\section{Data and empirical results}

\subsection{Data and descriptive statistics}

Data on the 1,430 firm commitment IPOs from January 1983 through September 1987 used in this study are compiled from Investment Dealers' Digesi

\footnotetext{
${ }^{3} I$ thank the referee for pointing this out.
} 
Corporate Database (IDD). IDD reports company, offering, and underwriting characteristics including the high and low anticipated offer prices quoted in the preliminary prospectus. Isslies that have missing values for either the high or low offer prices are excluded. The sample does not inciude unit offerings and bank stocks. In additior, the stock price or an IPO on the first trading day must be available from Stardard and Poor's Daily Stock Price Record: Over-theCounter for use in calculatins initial returns, defined as the unadjusted percent change in stock value from the final offer price to the first trading day price:

$$
R_{1}=\left(P_{1}-P_{0}\right), P_{0}
$$

where $P_{0}$ is the final offer price and $P_{1}$ is the first recorded closing or bid price.

In order to examine the descriptive statistics associated with revisions in the offer price, the sample is broken into three groups, reflecting the hypothesized type of information revealed in the pre-issue maket: 1) offerings with final offer prices that exceed the highest price quoted in the preliminary prospectus, i.e., those which have good information revealed, 2) offerings within the offer range of the preliminary prospectus, i.e., those which have little or no information disciosed, and 3) offerings with offer prices below the lowest pric quoied in the preliminary prospectus, i.e., those which have bad informatio ${ }_{1}$ revealed. On average, $10 \%$ of all IPOs increase the final offer price above the lımit of the offer range, $63 \%$ go public within the offer range, and $27 \%$ decrease the final offer price below the offer range; these percentages are fairly constant over the sample time period.

Table 1 presents descriptive statistics on the offering and firm characteristics for all IPOs according to the relation of the final offer price to the preliminary offer range. There appears to be little variation among categories in either the average dollar width or the average percent width of the offer range. The dollat width of the offer range is calculated as the difference between the highest and lowest anticipated offer prices quoted in the preliminary prospectus. The percent width is the dollar width divided by the lowest anticipated offer price. If the preliminary prospectus contains only a single price, the percent width of the offer range is zero. While the means differ slightly among categories, the median dollai and percent width for each category of IPOs are identical at $\$ 2.00$ and $16.7 \%$, respectively, indicating that the offer range is set to a preexisting 'industry' standard.

Table 1 also documents average values of the preceding year's revenue for the issuing firm, the expected offer price, the actual offer price, and the total proceeds of the offering (excluding the exercise of the overallotment option). Issues that revise the offer price outside (either above or below) the offer range have significantly larger revenues in the year preceding the IPO and higher expected offer prices than issues that are ultimately priced within the offer range. As noted earlier, changes in offer prices are often accompanied by changes in the 
Table 1

Mean descriptive statistics on offer ranges, revenues, offer prices, and total proceeds by relation of the final offer price to the offer range quoted in the preliminary prospectus. ${ }^{a}$ The data for the sample of 1,430 IPOs issued from January 1983 to September 1987 are from Investment Dealers' Digest Corporate Database. Medians are in brackets.

\begin{tabular}{|c|c|c|c|c|}
\hline & $\begin{array}{l}\text { All } \\
\text { IPOs }\end{array}$ & $\begin{array}{l}\text { Final offer } \\
\text { price less } \\
\text { than the } \\
\text { offer range }\end{array}$ & $\begin{array}{c}\text { Final offer } \\
\text { price } \\
\text { within the } \\
\text { offer range }\end{array}$ & $\begin{array}{l}\text { Final offer } \\
\text { price greater } \\
\text { than the } \\
\text { offer range }\end{array}$ \\
\hline Number of issues & 1,430 & 386 & 895 & 149 \\
\hline Percent of sample & & $27.0 \%$ & $62.6 \%$ & $10.4 \%$ \\
\hline Dollar width of offer range ${ }^{b}$ & $\begin{array}{l}\$ 1.54 \\
{[2.00]}\end{array}$ & $\$ 1.71$ & $\begin{array}{l}\$ 1.41 \\
{[2.00]}\end{array}$ & $\begin{array}{l}\$ 1.89 \\
{[2.00]}\end{array}$ \\
\hline Percent width of offer range ${ }^{b}$ & $\begin{array}{c}15.1 \% \\
{[16.7 \%]}\end{array}$ & $\begin{array}{l}15.5 \% \\
{[16.7 \%]}\end{array}$ & $\begin{array}{l}14.7 \% \\
{[16.7 \%]}\end{array}$ & $\begin{array}{l}15.9 \% \\
{[16.7 \%]}\end{array}$ \\
\hline Preceding year's revenue & $\begin{array}{l}\$ 59.4 \mathrm{~m} \\
{[18.8 \mathrm{~m}]}\end{array}$ & $\begin{array}{l}\$ 71.9 \mathrm{~m} \\
{[26.2 \mathrm{~m}]}\end{array}$ & $\begin{array}{l}\$ 49.1 \mathrm{~m} \\
{[15.5 \mathrm{~m}]}\end{array}$ & $\begin{array}{l}\$ 85.4 \mathrm{~m} \\
{[22.1 \mathrm{~m}]}\end{array}$ \\
\hline $\begin{array}{l}\text { Expected offer price in the } \\
\text { preliminary prospectus }\end{array}$ & $\begin{array}{l}\$ 10.45 \\
{[10.13]}\end{array}$ & $\begin{array}{l}\$ 11.96 \\
{[12.00]}\end{array}$ & $\begin{array}{l}\$ 9.35 \\
{[9.00]}\end{array}$ & $\begin{array}{l}\$ 13.10 \\
{[13.50]}\end{array}$ \\
\hline Actual offer price & $\begin{array}{l}\$ 9.95 \\
{[9.75]}\end{array}$ & $\begin{array}{l}\$ 9.24 \\
{[9.00]}\end{array}$ & $\begin{array}{l}\$ 9.30 \\
{[8.75]}\end{array}$ & $\begin{array}{l}\$ 15.70 \\
{[16.00]}\end{array}$ \\
\hline Total proceeds & $\begin{array}{l}\$ 16.04 \mathrm{~m} \\
{[9.75 \mathrm{~m}]}\end{array}$ & $\begin{array}{l}\$ 14.34 \mathrm{~m} \\
{[10.40 \mathrm{~m}]}\end{array}$ & $\begin{array}{l}\$ 14.15 \mathrm{~m} \\
{[7.50 \mathrm{~m}]}\end{array}$ & $\begin{array}{l}\$ 31.83 \mathrm{~m} \\
{[22.10 \mathrm{~m}]}\end{array}$ \\
\hline
\end{tabular}

a The offer range is defined as the lowest, $P_{\mathrm{L}}$, and highest, $P_{\mathrm{H}}$, anticipated values of the offer price as quoted in the preliminary prospectus. Final offer prices that are less than the offer range have values that are lower than $P_{L}$. In contrast, final offer prices that are greater than the offer range have values that are higher than $\boldsymbol{P}_{\mathrm{H}}$. Final offer prices within the offer range lie between $\boldsymbol{P}_{\mathrm{L}}$ and $\boldsymbol{P}_{\mathrm{H}}$.

${ }^{b}$ The dollar width of the offer range is defined as $P_{H}-P_{L}$. The percent width $f$ the offer range is $\left(\boldsymbol{P}_{\mathrm{H}}-\boldsymbol{P}_{\mathbf{L}}\right) / \boldsymbol{P}_{\mathbf{L}}$.

'The expected offer price is defined as $\left(P_{\mathrm{H}}+P_{\mathrm{L}}\right) / 2$.

d Total proceeds exclude the exercise of the overallotment option.

number of shares offered. Thus, issues whose final offer price exceeds the offer range have significantly greater actual offer prices and total proceeds.

Table 2 presents changes in the offer price, number of shares offered, and total proceeds from the time of the filing of the preliminary prospectus to the offer date. In order to examine the relative change in offer price for all categories of IPOs, the percent difference between the expected offer price and the actual offer price is calculated as:

$$
\text { Change in offer price }=\left(P_{O}-P_{E}\right) / P_{E} \text {, }
$$

where $P_{\mathrm{E}}$ is the expected offer price and is defined as $\left(P_{\mathrm{H}}+P_{\mathrm{L}}\right) / 2, P_{\mathrm{H}}$ is the highest price in the offer range, $P_{\mathrm{L}}$ is the lowest price in the offer range, and $P_{\mathrm{O}}$ is the final offer price. 
Table 2

Mean percent change in the offer price and the number of shares offered, and changes in the total proceeds from thi filing of the preliminary prospectus to the offer date, by relation of the final offer price to the offer range quoted in the preliminary prospectus. ${ }^{a b} b$ The data for the sample of 1,430 IPOs issued from January 1983 to September 1987 are from Investment Dealers' Digest Corporate Datubase. Medians are in brackets.

\begin{tabular}{|c|c|c|c|c|}
\hline & $\begin{array}{l}\text { All } \\
\text { IPOs }\end{array}$ & $\begin{array}{l}\text { Final offer } \\
\text { price less } \\
\text { tlian the } \\
\text { offer range }\end{array}$ & $\begin{array}{l}\text { Final offer } \\
\text { price } \\
\text { within the } \\
\text { offer range }\end{array}$ & $\begin{array}{l}\text { Final offer } \\
\text { price greater } \\
\text { than the } \\
\text { offer range }\end{array}$ \\
\hline $\begin{array}{l}\text { Mean percent difference from } \\
\text { the expectid offer price to } \\
\text { the final offer price }\end{array}$ & $\begin{array}{l}-4.3 \% \\
{[0.0 \%]}\end{array}$ & $\begin{array}{l}-22.4 \% \\
{[-21.2 \%]}\end{array}$ & $\begin{array}{l}-0.6 \% \\
{[0.0 \%]}\end{array}$ & $\begin{array}{l}20.9 \% \\
{[19.6 \%]}\end{array}$ \\
\hline $\begin{array}{l}\text { Mean percent difference in } \\
\text { high or low anticinated price } \\
\text { and the final offer price }\end{array}$ & & $\begin{array}{l}-16.5 \% \\
{[-15.0 \%]}\end{array}$ & & $\begin{array}{l}12.7 \% \\
{[10.0 \%]}\end{array}$ \\
\hline $\begin{array}{l}\text { Mean percent change in the } \\
\text { number of shares offered }\end{array}$ & $\begin{array}{l}-0.8 \% \\
{[0.0 \%]}\end{array}$ & $\begin{aligned}- & 10.0 \% \\
& {[0.0 \%] }\end{aligned}$ & $\begin{array}{l}1.4 \% \\
{[0.0 \%]}\end{array}$ & $\begin{array}{l}10.0 \% \\
{[5.3 \%]}\end{array}$ \\
\hline $\begin{array}{l}\text { Fercent of IPOs ihat have a } \\
\text { positive change in sil ires }\end{array}$ & $19.7 \%$ & $7.8 \%$ & $19.0 \%$ & $54.4 \%$ \\
\hline $\begin{array}{l}\text { Average doliar value difierence } \\
\text { istwe act:us' and expectces } \\
\text { proceeds quoted in the } \\
\text { preliminary prospectus' }\end{array}$ & $\begin{array}{l}\$ 09 \mathrm{~m} \\
{[0.0 \mathrm{~m}]}\end{array}$ & $\begin{array}{l}-\$ 6.5 \mathrm{~m} \\
{[-4.4 \mathrm{~m}]}\end{array}$ & $\begin{array}{l}\$ 0.01 \mathrm{~m} \\
{[0.0 \mathrm{~m}]}\end{array}$ & $\begin{array}{l}\$ 8.0 \mathrm{~m} \\
{[5.0 \mathrm{~m}]}\end{array}$ \\
\hline $\begin{array}{l}\text { Average ratio of actual proceeds } \\
\text { to the expected proceeds quoted } \\
\text { in the preli-inary prospectus }\end{array}$ & $\begin{array}{c}0.96 \\
{[1.00]}\end{array}$ & $\begin{array}{c}0.70 \\
{[0.72]}\end{array}$ & $\begin{array}{c}1.01 \\
{[1.00]}\end{array}$ & $\begin{array}{l}1.33 \\
{[1.28]}\end{array}$ \\
\hline $\begin{array}{l}\text { Average ratio of actual proceeds } \\
\text { to the minimum proceeds quoted } \\
\text { in the preliminary prospectus }\end{array}$ & $\begin{array}{c}1.03 \\
{[1.00]}\end{array}$ & $\begin{array}{c}0.75 \\
{[0.78]}\end{array}$ & $\begin{array}{c}1.08 \\
{[1.05]}\end{array}$ & $\begin{array}{c}1.44 \\
{[1.38]}\end{array}$ \\
\hline $\begin{array}{l}\text { Average ratio of actual proceeds } \\
\text { to the maximum proceeds quoted } \\
\text { in the preliminary prospectus }\end{array}$ & $\begin{array}{c}0.90 \\
{[0.92]}\end{array}$ & $\begin{array}{c}0.66 \\
{[0.67]}\end{array}$ & $\begin{array}{c}0.95 \\
{[0.98]}\end{array}$ & $\begin{array}{l}1.24 \\
{[1.20]}\end{array}$ \\
\hline
\end{tabular}

${ }^{a}$ All of the numbers presented exclude the exercise of the overallotment option.

'The offer range is defined as the lowest, $P_{\mathrm{L}}$, and highest, $\boldsymbol{P}_{\mathrm{H}}$, anticipated values of the offer price as quoted in the preliminary prospectus. Final offer prices that are less than the offer range have values that are lower $P_{\mathrm{L}}$. In contrast, final offer prices that are greater than the offer raitge have values that are higher than $P_{\mathrm{H}}$. Final offer prices within the offer range ie between $\boldsymbol{P}_{\mathrm{L}}$ and $\boldsymbol{P}_{\mathrm{H}}$.

'The percent difference from the expected offer price to the final offer price is calculated as $\left(P_{\mathrm{O}}-P_{\mathrm{E}}\right) / P_{\mathrm{E}}$, where $P_{\mathrm{O}}$ is the final offer price and $P_{\mathrm{E}}=\left(P_{\mathrm{H}}+P_{\mathrm{L}}\right) / 2$ is the expected offer price.

The percent difference in the high or low anticipated offer price to the final offer $F_{-}$ce is defined as (1) $\left(P_{O}-P_{L}\right) / P_{L}$ for issues with actual offer prices less than the expected offer price and (2) $\left(P_{\mathrm{O}}-P_{\mathrm{H}}\right) / P_{\mathrm{H}}$ for issues with actual offer prices greater than the expected offer price.

e The percent change in shares offered is defined as $\left(N_{\mathrm{O}}-N_{\mathrm{F}}\right) / N_{\mathrm{F}}$, where $N_{\mathrm{O}}$ is the actual nur.ber of shares offered and $N_{F}$ is the number of shares quoted in the preliminary prospectus.

Actual proceeds are calculated as $\left(N_{\mathrm{O}} * P_{\mathrm{O}}\right)$ and the average proceeds quoted in the preliminary prospectus are defined as $\left(N_{\mathrm{F}} * P_{\mathrm{E}}\right.$. Minimum preliminary proceeds are $\left(N_{\mathrm{F}} * P_{\mathrm{L}}\right)$ and maximum preliminary proceeds are $\left(N_{\mathrm{F}} * P_{\mathrm{H}}\right)$. 
The results of table 2 indicate a substantial revision in the terms of the offering for issues whose final offer price is above or below the offer range, while the median revision in offer price for the sample as a whole is zero. Offerings that go public below the offer range have final offer prices that are, on average, $22.4 \%$ less than expected, while offerings above the offer range have final offer prices that are, on average, $20.9 \%$ above the expected offer price.

For issues below the offer range, the difference between the final offer price and the lowest price in the offer range $\left[\left(P_{\mathrm{O}}-P_{\mathrm{L}}\right) / P_{\mathrm{L}}\right]$ is $-16.5 \%$. Similarly, if the offer price is above the offer range, the percent difference from the actual offer price to the highest offer price in the offer range $\left[\left(P_{O}-P_{H}\right) / P_{H}\right]$ is $12.7 \%$.

Changes in the offer price from the filing of the preliminary prospectus to the offer date are often accompanied by charges in the number of shares offered. Since IDD does not separately report the number of shares filed in the preliminary prospectus that are sales by insiders, the changes in proceeds are to both the issuing firm and any seliing inside sharehoiders. In additi $n$, the number of shares filed and subsequently offered does not include the amount of the overallotment option. On average, the number of shares issued is increased (decreased) by $10 \%$ if the final offer price is above (below) the ofier range. Furthermore, issues abcve the offer range are approximately three (seven) times more likely to increase the number of shares than issues that are within (below) the offer range. The median percent change in the number of shares issued is zero for all categories except issues whose offer price exceeds the offer range. Although an exact test of changes in allocation to investors revealing good information is impossible due to the lack of data on indications of interest in IPOs, an increase in the number of shares offered for issues with good information is consistent with a model in which truth-telling is partially compensated with greater share allocation.

Since changes in the offer price are often accompanied by changes in the number of shares offered, the total proceeds of the issue also change. In table 2, the change in proceeds is examined by comparing the actual proceeds on the offer date to the expected proceeds listed in the preliminary prospectus, excluding the exercise of the overallotment option. The expected proceeds are calculated as the number of shares registered multiplied by $t_{\text {. }}$; expected offer price quoted in the preliminary prospectus. in general, there is no difference between the median actual and expected proceeds for the full sample of IPOs.

When the sample is broken down by revisions in the offer price, issues above the offer range increase the amount issued by $\$ 8.0$ million, for a ratio of actual-to-expected procieds of 1.33 . In addition, issues above the offer range receive $124 \%$ of the maximum proceeds (the prelimina y number of shares multiplied by the highest price in the offer range) disclosed in the preliminary prospectus. By conirast, issues below the offer range raise $\$ 6.5$ million less than expected, for a ratio of actual-to-expected proceeds of 0.70 . In addition, these isstes receive only $75 \%$ of the minimum proceeds (the preliminary number of 
shares multiplied by the lowest price in the offe, ange statied in the preliminary prospectus.

One consequence for a firm whose offer prize falls below the offer range is that the SEC can require the firm to file an amendment to the registration statement stating the reason for and effect of lowering the offer price. The Commission can also require the firm to recirculate a revised preliminary prospectus to the selling group and/or investors who have made indications of interest in the waiting period. It is not surprising, therefore, that issues that lower the offer price spend more time in registration than do all oiher IPOs. The averese length of time from the filing of the preliminary prospectus to the offer date is 64 days ior IPOs below the offer range, compared to 48 days for IPOs above the offer range. Offerings within the offer range spend, on average, 56 days in registration.

These results indicate that changes in the offer price are often accompanied by changes in the number of shares offered, affecting the total proceeds to the issuing firm. Further, a decline in the expected proceeds can require a firm. to comply with additional regulatory demands that potentially affeci the abiiity of the underwriter to time the issue advantageously.

\subsection{Determinaits of revisions in offer prices}

Benveniste and Spindt argue that revisions in the offer price are the result of information collected by underwriters during the waiting period. In order to examine the influence of pre-selling activities and other aspects of the IPO process on changes in the offer price, a cross-sectional ordinary least squares (OLS) regression analysis of the absolute revision in offer price, measured as $\left|P_{\mathrm{O}}-\boldsymbol{P}_{\mathrm{E}}\right| / \boldsymbol{P}_{\mathrm{E}}$, is undertaken using several independent variables: the width of the offer range, the expected proceeds of the offering (prior to the issue), the absolute change in the market during the waiting period, the size of the overallotment option, the market share of the underwriter, and the percent of the issue held by institutions one quarter after the offering.

Benveniste and Spindt hypothesize that firms that have greater uncertainty surrounding the true value of the shares are more likely to have revisions in their offer price. The ex ante risk of an issue is measured as both the percent width of the offer range and the expected size of the offering. Underwriters who are unsure of the price of an issue are likely to set wider offer ranges to provide greater flexibility in setting the final offer price. The wider the offer range, therefore, the greater the uncertainty about the true value of the issue. In addition, the size of the offering is hypothesized to be inversely related to changes in the offer price. Ritter (1987) documents that the aftermarket standard deviation of returns is regatively correlated with issue size.

The absolute parcent change from the file date to the offer date in the equally-weighted NASDAR index of the Center for Research in Security Prices is expected to be positively ielated to changes in the offer price. If information 
gathered during the waiting period indicates that the market will decline (increase) around the time of the offering, investmen' bankers will revise their expectation of the value of the firm's stock downward (upward) to reflect both the prevailing market conditions and to stimulate (meet) deinand in a falling (rising) market.

An empirical extension of the model, noted by Benveniste and Spindt, is that the overallotment option reduces the incentive for the underwriter to pre-sell the issue and thereby gather information from regular investors durng the waiting period. Therefore, the greater is the available overallotment opiion, the lower will be the change in the offer price. The number of shares available for use in the overallotment option is contained in the IDD database and is expressed here as a percent of the number of shares offered.

The experience of the underwriter is included as an independent variabie to capture two potential explanations for changes in offer prices. The first explanation is that smaller, inexperienced underwriters may be less likely to have the expertise necessary to evaluate the firm a..d are therefore more likely to misprice the issue. If this is the case, the market share of the lead underwriter will be negatively related to changes in the offer price. The second explanation is that larger, experienced underwriters are able to sell to a greater pool of informed investors who provide valuable information during the waiting period. Therefore, changes in the offer price will be positively related to the experience or reputation of the lead underwriter. The market share of the underwriter is used as a measure of the experience and reputation of the investment banker and is calculated as the cumulative dollar amount underwritten by an underwriter from 1983 to 1987 divided by the total dollar amount of all IPOs brought to market. The total market value of equity raised by all 2,644 offerings classified as IPGs by IDD's Corporate Database from 1983 through 1987 is $\$ 70.3$ billion. As an example of how the market share of the underwriter is calculated, Merrill Lynch Capital Markets has the largest share of the IPO market at almost $\$ 16$ billion or $22 \% .{ }^{4}$ Since many of the issues have more than one lead underwriter, the market shares of all lead investment bankers are then averaged.

Finally, the percent of the cffer amount (net of the overallotment option) held by institutional managers one quarter following the offering is used as proxy for

\footnotetext{
${ }^{4}$ The market share of the underwriter as a measure of either reputation or experience is compared to the rankings of Carter and Manaster (1990) in Megginson and Weiss (1991). The market share of the underwritcr is shosen rather than the Carter and Manaster rankings for two reasons. First, the Carier and Manaster sample used in calculating the ranks of the underwriters ends in the year this study begins. Using their rankings assumes that rcputational capital and/or experience of invesiment bankers does not change over time. However, this ass'mption is challenged by Beatty and Ritter (1986) and the recent deciine of many firms in the investment banking community. Second, the market share of the underwriter is cardinal, versus the ordinal values of the Carter and Manaster rankings (although comparison of the two measures indicates a high degree of positive correlation).
} 
how much of the issue is pre-sold to regular investors. The greater the pre-selling activities to regular investors, the more likely it is that information is revealed about the true value of the issue, in wi. " case there will be a positive relation between absolute revisions in the offer price and institutional holdings. The post-offering holdings of institutions are used as a measure of the pre-issue participation by regular investors, since information on the pre-issue selling activities of urderwriters to regular investers is unavailajle. Data on institutional holdings are from Spectrum 3: 13(f) Institutional Stock Holdings Survey, which reports on a quarterly basis the holdings by institutional managers who control $\$ 100$ million or more in equity and who are required to report theiholdings to the SEC on Form 13-F at the end of each quarter.

Table 3 presents the OLS regressions and White (1980) heteroskedasticconsistent $t$-statistics. There is a positive and significant coefficient on the width oi the offer range, indicating that the wider the offer range, the greater is the absolute change in the final offer price. The expected size of the issue, however, is not significantly related to changes in the offer price.

As expected, changes in the market from the filing of the preliminary prospectus to the offer date are positively associated with changes in the offer price. Increases in the offer price are associated with a rise in the market index during the waiting period while, conversely, final offer prices are decreased when the market falls.

Although insignificant, the sign of the coefficient on the size of the overallotment option is consistent with the predictions of Benveniste and Spindt. Larger overallotment options lower the need to pre-sell the issue and reduce the absolute perent change in the offer price.

The reputation or experiense of the underwriter is positively and significantiy related to revisions in offer prices. In other words, issues underwritten by experienced underwriters are more likely to have revisions in the offer price, in either direction, than IPOs brought to market by less-experienced underwriters. This finding is corsistent with the explanation that large: underwriters are able to seif to a bigger pool of regular investors, so that these underwriters are more likely during the waiting period to gather valuable information that affects the final offer price.

Lastly, the greater the participation of institutions, as measured by their post-issue holdings, the higher is the absolute change in the offer price. This relation is consistent with the bypothesis that regular investors revea! information to the underwriter. Further, this result indicates that institutional investors drive IPO pricing more than retail investors.

The precuins, analysis indicates that the risk of the issue, the market conditions surrounding the time of the offering, and the pre-selling activities of underwriters affect the choice of the final offer price. The next section examines the extent to which changes in the offer price are accompanied by changes in share allosation and subsequent undeipiicing. 


\section{Tabie 3}

Cross-sectional OLS regressions with the absolute percent change in the actual offer price from the expected offer price, the percent change in the numier of shares offered, and initial returns as dependent as variables. ${ }^{\mathrm{a}}$ The data for the sample of IPOs issued frnm January 1983 to September 1987 are from Investment Dealers' Digesi Corporate Database.

\begin{tabular}{|c|c|c|c|}
\hline & \multicolumn{3}{|c|}{ Dependent variables } \\
\hline & $\begin{array}{l}\text { Absolute percent change in } \\
\text { the actual offer price from } \\
\text { the expected offer price in } \\
\text { the preliminary prospectus }\end{array}$ & $\begin{array}{l}\text { Percent change in } \\
\text { shares offered }\end{array}$ & $\begin{array}{l}\text { Inıtial } \\
\text { return" }\end{array}$ \\
\hline Intercept & $\begin{array}{l}0.051^{\mathrm{B}} \\
(5.68)\end{array}$ & $\begin{array}{r}0.001 \\
(0.14)\end{array}$ & $\begin{array}{l}0.124^{8} \\
(7.38)\end{array}$ \\
\hline $\begin{array}{l}\text { Percent change in the actual offer } \\
\text { price from the expected offer price } \\
\text { quoied in the preliminary prospectus }\end{array}$ & & $\begin{array}{l}0.365^{\mathrm{g}} \\
(7.93)\end{array}$ & $\begin{array}{l}0.383^{8} \\
(11.01)\end{array}$ \\
\hline $\begin{array}{l}\text { Percent width of preliminary } \\
\text { prospectus offer range }\end{array}$ & $\begin{array}{l}0.248^{8} \\
(9.24)\end{array}$ & & \\
\hline Offer amount ${ }^{e}$ & $\begin{array}{r}0.001 \\
(1.50)\end{array}$ & $\begin{array}{l}-0.001^{\mathrm{h}} \\
(-2.21)^{2}\end{array}$ & $\begin{array}{l}-0.001^{\mathrm{B}} \\
(-2.98)\end{array}$ \\
\hline $\begin{array}{l}\text { Percent change in the NASDAQ index } \\
\text { from file d } \% ; \text { to ofier date }\end{array}$ & $\begin{array}{l}0.169^{\mathrm{h}} \\
(2.46)\end{array}$ & $\begin{array}{l}0.381^{8} \\
(4.53)\end{array}$ & $\begin{array}{l}0.410^{\circ} \\
(5.65)\end{array}$ \\
\hline $\begin{array}{l}\text { Ratio of overallotment option shares } \\
\text { available to shares offered }\end{array}$ & $\begin{array}{l}-0.052 \\
(-1.07)\end{array}$ & & $\begin{array}{l}-0.004 \\
(-0.03)\end{array}$ \\
\hline $\begin{array}{l}\text { Average maiket share of the } \\
\text { lead underwriters }\end{array}$ & $\begin{array}{l}0.271^{8} \\
(3.42)\end{array}$ & & $\begin{array}{l}-0.327^{\mathrm{E}} \\
(-4.18)\end{array}$ \\
\hline $\begin{array}{l}\text { Percent of issue held by institutions } \\
\text { the ciuarte; following the offer }\end{array}$ & $\begin{array}{l}0.020^{\mathrm{h}} \\
(2.39)\end{array}$ & $\begin{array}{l}0.045^{h} \\
(2.62)\end{array}$ & $\begin{array}{l}-0.021 \\
(-1.46)\end{array}$ \\
\hline F.vaiue & 28.18 & 65.97 & 50.51 \\
\hline Adjusted $R^{2}$ & $10.62 \%$ & $15.46 \%$ & $17.80 \%$ \\
\hline Number of observations & 1373 & 1373 & 1373 \\
\hline
\end{tabular}

a In parentheses are the $t$-statistics using White (1980) heteroskedastic-consistent standard errors.

"The absolute change in the offer price is calculated as $\left|\left(P_{\mathrm{O}}-P_{\mathrm{E}}\right) / P_{\mathrm{F}}\right|$, where $P_{\mathrm{O}}$ is the final offer price, $P_{\mathrm{E}}=\left(P_{\mathrm{H}}+P_{\mathrm{L}}\right) / 2$ is the expected offer price, $P_{\mathrm{I}}$ is the highest anticipated offer price, and $P_{\mathrm{L}}$ is the lowest anticipated offer price quoted in the preliminary prospectus.

'The percent change in shares offered is defined as $\left(N_{\mathrm{O}}-N_{\mathrm{F}}\right) / N_{\mathrm{F}}$, where $N_{\mathrm{O}}$ is the actual number of shares offered (net of the overallotment option exercised) and $N_{F}$ is the number of shares quoted in the preliminary prospectus.

dhe initial return is defined as $\left(P_{1}-P_{0}\right) / P_{0}$, where $P_{1}$ is the first recorded closing or bid price after the offering.

'The offer amount is the pre-issue or expected offer amount when used as an independent variable for both the absolute change in the offer price and the percent change in shares offered. and is the post-issue or actual offer amount (excluding the exercise of the overallotment option) when used as an independent variable for the initial return.

'The change in the NASDAQ index is measured in absolute terms when used as an independent variable for the absolute change in offer price.

BSignificant at the 0.01 leve! (two-tailed test).

hSignificant at the 0.05 level (two-tailed test). 


\subsection{Share allocation and is itiai returns}

In the Benveniste and Spirsit mods!. investore are compensated for revealing good information by a pricing a... alloca se s sedule that maximizes their expected profit. This section cxamiacs an has the compensation schedule proposed by Benveniste and Spindit is rata usion in practice.

The preceding analysis indicates thrt revisions in offer prices are often accompanied by revisions in the size of the issue. A specific test of the relation between changes in share allocation and reveintion of information is not possible given the lack of data on pre-issue indications of interest and subsequent actual distribution. However, two variables can be used to proxy for changes in allocation: the use of the overallotment option and the percent change in shares offered. A greater frequency of use of the overallotment option and $:$ positive change in the number of shares issued for IPOs that have good information revealed are both consistent with an increase in share aliocation as partial compensation for truth-teling. However, the absence of an increase in the number of shares issued, whether by an increase in offer size or through the exercise of the overallotment option, does not necessarily mean that share allocation is not used as compensation to regular investors. It is certainly possible that the original number of shares to be issued is sufficient to compensate investors.

Information on the amount of the overallotment option available for use by the underwiter for the entire sample time period is contained in IDD. Data on the actual exercise of the overallotment option, however, is bimited to the years 1985 and later. Examining the frequency of use of the overallotment option from 1985 to 1987 indicates that $85 \%$ of the issues with offer prices above the offer range exercise the overallotment option, compared to $68 \%$ and $54 \%$ for issues with offer prices within and below the offer range, respectively. This higher frequency of use of the overallotment option is consistent both with greater demand for issues that have good information revealed and with an increase in the allocation of shares to investors who truthfully reveal their demand.

Table 3 presents the results of an OLS regression using the percent change in shares offered, which proxies for changes in share allocation, as the dependent variable. The percent change in the offer price, the pre-issue offer size, the percent change in the NASDAQ index, and the level of institutional hoidings are used as independent variables.

Positive (negative) information regarding the issue is reflected in final offer prices that are greater (less) than expected. If increased allocations are used to at least partially compensate investors for revealing information, then positive revisions in the number of shares issued should be associated with positive revisions in the offer price. Similar to table 2 , there is a positive and significant relation between revisions : the offer price and changes in the number of shares offered. 
Benveniste and Spindt also suggest that the ex ante marginal value of information is related to the uncertainty surrounding the issue. In particular, the authors refer to Beatty and Ritter (1986), who argue that smaller issues have greater $e x$ onte uncertainty than larger issues. If information is more valuable for smaller issues, then the percent change in shares offered, as a proxy for the change in share allocation, will be negatively related to the pre-issue size of the offering. Censistent with this prediction, the coefficien: on pre-issue size is negative and significant.

Changes in the market during the waiting period affect the number of shares to be issued. The coefficient on the change in the NASDAQ index is positive and significant, verifying that declines (increases) in the market during the pre-issue period result in the number of shares being reduced (increased).

The percent of the offering held by institutions one quarter after the ofiering is included as a test vi the hypothesis that investors who reyeal good information through demanci are compensated in part by greater share allocation. Revisions in shares offered are positively related to the holdings of instituiions one quarter following the offering. Therefore, the greater the demand by institutions, the higher is the percent change in the offer size.

The results of the regression using percent change in shares offered as the dependent variable indicate that share aliocation increases when good information is revealed and decreases when bad information is revealed. This finding is consistent with a model in which share allocation is used as partial compensation to investors for providing truthful information.

If demand for the issue is very high (i.e., there are many investors revealing good information) and the issue is oversubscribed, then underwriters may not be able to fully compensate investors for their truthful revelations by simply increasing the number of shares to be issued. Hence, if shares are rationed, the offer price will only partially adjust to good information, and underpricing will be used in conjunction with increased share allocation to reward investors for truth-telling. An empirical prediction of Benveniste and Spindt is that with share rationing, issues for which good information is revealed will have greater underpricing than issues for which bad or no information revealed. Therefore, the level of initial returns will be positively related to revisions in the offer price.

Fig. 1 presents the average initial return by year according to the relation of the final offer price to the offer range. The results in fig. 1 indicate a positive relation between revisions in the offer price and the subsequent initial return. (The median first-day returns for each year tollow the same general pattorn as the mean initial returns.) In general, issues that have good information revealed (final offer prices that exceed the offer range) have substantially greater initial returns than all other IPOs. Interestingly, the initial trading day volume as a percent of the number of shares issued excluding the exercise of the overallotment option $(47 \%)$ is also higher for issues whose offer prices exceed the offer range compared to issues whose final offer prices are within the offer range 


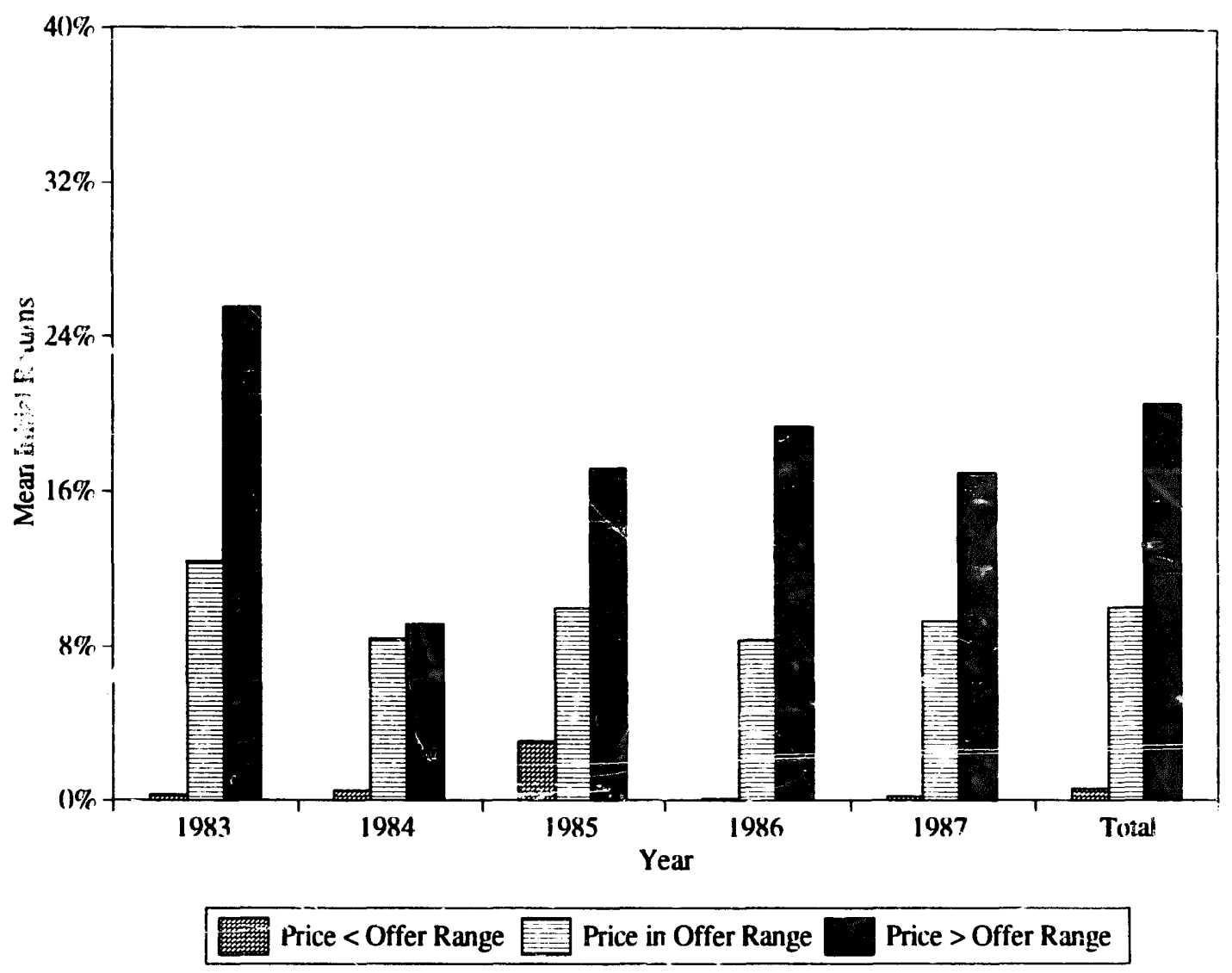

Fig. 1. Mean yearly initial returns by relation of the final offer price to the offer range quoted in the preliminary prospectus. The offer range is defined as the lowest, $\boldsymbol{P}_{\mathrm{L}}$, and highest, $\boldsymbol{P}_{\mathrm{H}}$, anticipated values of the offer price as quoted in the preliminary prospectus. Final offer prices that are less than the offer range have values that are lower than $P_{L}$. In contrast, final offer prices that are greater than the offer range have values that are higher than $\boldsymbol{P}_{\mathrm{H}}$. Final offer prices within the offer range lie between $P_{\mathrm{L}}$ and $P_{\mathrm{H}}$. The initial return is defined as $R_{1}=\left(P_{1}-P_{\mathrm{O}}\right) / P_{\mathrm{O}}$, where $P_{\mathrm{O}}$ is the final offer price and $P_{1}$ is the first recorded closing or bid price from Standard and Poor's Daily Stock Price Record: Over-the-Counter. The data for the sampie of 1,430 IPOs issued from January 1983 to September 1987 are from Investment Dealers' Digest Corporate Database.

$(28 \%)$ and below the offer range $(26 \%)$. Furthermore, this relation holds for up to two years into the future.

The mean initial return over the entirc sample period for firms going public above the offer range is $20.7 \%$. Offerings that go public below the offer range quoted in the preiminary prospectus have an average initial return of $0.6 \%$, which is not significantly different from zero. The remaining issues, consisting of offerings within the offer range, have an average initial return of $10.0 \%$. The differences in initial returns between each of these three categories are significant at the $1 \%$ level. Further, offerings that have good information revealed have a greater frequency of positive returns on the first trading day; of the issues with final offer prices exceeding the offer range, $89 \%$ have an increase in value on the 
first trading day, compared to $62 \%$ of the issues within the offer range and $33 \%$ of the issues below the offer range.

The absence of underpricing for issues priced below the offer range is also consistent with the empirical implications of the Benveniste and Wilhelm (1990) model which combines the analyses of Rock (1986) and Benveniste and Spindt to include both retail and regular investors. The model predicts that when negative information is revealed in the pre-issue market, the issue will not be underpriced. [For further evidence supporting the model, in particular the actual allocation of shares in an IPO between retaii and institutional investors, see Hanley and Wilhelm (1993).]

The results of the regression with initial returns as the dependent variable are presented in table 3. Again, all standard errors are adjusted for heteroskedasticity [White (1980)]. The independent variables include those used in the regression equation that had the percent change in shares as the dependent variable, as well as two additional independent variables: the ratio of the overallotment option available to the number of shares ofiered and the market share of the underwriter.

Benveniste and Spindt predict that if it is not possible to completely compensate truth-telling through increased share allocation, then underpricing must also be uied to compensate investors for revealing good information. Consistent with this prediction, initial returns are positively and significantly related to the percent change in the offer price from the filing of the preliminary prospectus to the offer date. Underpricing is highest (lowest) when offer prices are increased (decreased) and positive (negative) information is revealed during the waiting period.

The actual offer amount (excluding the overallotment option) is used as a dependent variable to capture not only the riskiness or uncertainty of an issue but also changes in allocation generated by changing the number of shares to be issued. Similar to the findings of Ritter (1987), smaller issues tend to have greater underpricing than larger issues. This result can be attributed to two factors: 1) initial returns increase as the marginal value of information increases (size decreases), and 2) initial returns decrease as share allocation (issue size) increases.

The percent change in the NASDAQ index from the filing of the preliminary prospectus to the offer date is positively and significantly related to underpricing. Increases (decreases) in initial returns are associated with positive (negative) changes in the market during the waiting period.

Benveniste and Spindt (1989) and Ritter (1987) predict that larger overallotment options reduce underpricing when demand is high because the underwriter substitutes increased allocation for higher initial returns as compensation to regular investors. Although the coefficient on the ratio of the overallotment to the amount offered is insignificant, the sign of the coefficient is consistent with both the predictions of the model and the findings of Welch (1991). 
The market share of the underwriter, as a proxy for quality, is inversely related to underpricing. As in Carter and Manaster (1990), high-quality underwriters, with inore reputational capital at stake, certify that the issue price is consistent with the information available at the offer date. Issues underwritten by more reputable investment banks thus have less underpricing than issues brought to market by lower-quality underwriters.

The percent of the offering held by institutions one quarter after the offering is included as a test for two hypotheses. First, Benveniste and Spindt argue that investors who reveal good information through demand are compensated, in part, by greater underpricing than issues that have either bad or no information revealed. Therefore, if institutional holdings proxy for the demand of an issue, the larger the institutional holdings, the higher should be the initial return. Second, an alternative hypothesis predicted by Benveniste and Spindit is that underwriters can use their leverage with regular investors to require them to purchase shares in an offering that is overpriced in order to allow them to participate in futire underpriced offerings. Including certain investors on a regular basis in the pre-marketing activities of IPOs provides them with a significant average return. 'These profits can be used occasionally to induce investors to take a badly received IPO off the underwriter's hands' [Benveniste and Spindt $(1989$, p. 354)].

The coefficient on the percent of the issue held by institutions one quarter after the offering is negative but insignificant. This result is consistent with the hypothesis that underwriters require regular customers to buy shares in issues that are overpriced so that these customers can purchase shares in future underpriced offerings. As further evidence in support of this hypothesis, the level of institutional holdings is broken into three categories based on the relation of the final offer price to the preliminary offer range. As expected, institutions hold the largesi average fraction (44\%) of the issue in IPOs whose ofier price is above the offer range. Note, however, that institutions hold the next-largest fraction $(32 \%)$ of issues whose offer price is below the offer range. The lowest amount of institutional participation $(23 \%)$ is in issues that are priced within the offer range.

The findings of this section indicate that both increased share allocation and underpricing are used as compensation to investors for revealing good information. In addition, the relation of the final offer price to the offer range disclosed in the preliminary prospectus is a good predictor of the level of initial returns.

\section{Long-run performance}

Ritter (1?91) presents some evidence that firms with high adjusted initial returns tend to have the worst aftermarket performance. He attributes his findings to potential overreaction in the market for IPOs and suggests that this 
result may 'shed light on the 'partial adjustment' phenomenon' (p. 15). This section examines the long-run performance of IPOs according to the revision in offer prices to see whether or not issues with final offer prices above the offer range have larger price declines from the second trading day onward than issues within or below the offer range.

Table 4 documents the returns over a two-year time horizon for IPOs with final offer prices below, within, and above the offer range. Long-run returns are defined as

$$
R_{2 \mathrm{yr}}=\left[\left(P_{2 \mathrm{yr}}+D I V-P_{2}\right) / P_{2}\right]-\left[\left(I_{2 \mathrm{yr}}-I_{2}\right) / I_{2}\right],
$$

where $P_{2 y r}$ is the price at the end of the two-year time horizon, $P_{2}$ is the closing or bid price on the second trading day, DIV is dividends paid, $I_{2 y r}$ is the value of the equally-weighted NASDAQ index over the same two-year time horizon as $P_{2 y r}$, and $I_{2}$ is the value of the equally-weighted NASDAQ index on the second day of trading of the IPO.

Table 4

Long-run NASDAQ-adjusted returns by the relation of the final offer price to the offer range quoted in the preliminary prospectus. ${ }^{a}$ All return data are from the CRSP NASDAQ tapes. The data for the original sample of 1,430 IPOs issued from January 1983 to September 1987 are from Investment Dealc's' Digest Corporate Database. Medians are in brackets.

\begin{tabular}{lcccc}
\hline & $\begin{array}{c}\text { All } \\
\text { IPOs }\end{array}$ & $\begin{array}{c}\text { Final offer } \\
\text { price less } \\
\text { than the } \\
\text { offer range }\end{array}$ & $\begin{array}{c}\text { Final offer } \\
\text { price } \\
\text { within the } \\
\text { offer range }\end{array}$ & $\begin{array}{c}\text { Final offer } \\
\text { price greater } \\
\text { than the } \\
\text { offer range }\end{array}$ \\
\hline $\begin{array}{l}\text { Number of issues } \\
\text { Mean adjusted }\end{array}$ & 1051 & 273 & 668 & 110 \\
$\begin{array}{l}\text { two-year return } \\
\text { c }\end{array}$ & $-16.8 \%$ & $-17.4 \%$ & $-17.1 \%$ & $-13.8 \%$ \\
$\begin{array}{l}\text { Percent of offerings with } \\
\text { positive two-year returns }\end{array}$ & {$[-37.2 \%]$} & {$[-39.1 \%]$} & {$[-38.4 \%]$} & {$[-31.0 \%]$} \\
\end{tabular}

a The offer range is defined as the lowest, $P_{\mathrm{L}}$ and highest, $\boldsymbol{P}_{\mathrm{H}}$, expected values of the offer price as quoted in the preliminary prospectus. Final offer prices that are less than offer range have values that are lower $\boldsymbol{P}_{\mathrm{L}}$. In contrast, final offer prices the.t are greater than the offer ra tige have values that are higher than $\boldsymbol{P}_{\mathrm{H}}$. Final offer prices within the offer range lie between $\boldsymbol{P}_{\mathrm{L}}$ and $\boldsymbol{P}_{\mathrm{H}}$.

${ }^{b}$ The sample used for long-run returns incl!nde. - nity those isstes that have retlirns after two years of seasoning.

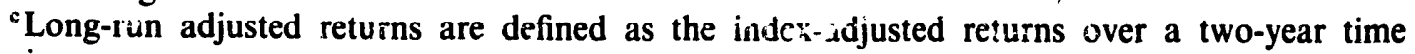
horizon:

$$
R_{2 \mathrm{yr}}=\left[\left(P_{2 \mathrm{yr}}+D I V-P_{2}\right)_{i} P_{\zeta}\right]-\left[\left(I_{2 \mathrm{yr}}-I_{2}\right) / I_{2}\right],
$$

where $\boldsymbol{P}_{2 y \mathrm{r}}$ is the price at the end of the two-year time horizon, $\boldsymbol{P}_{2}$ is the closing or bid price on the second trading day, DIV are the dividends paic $I_{2 y \mathrm{r}}$ is the value of the equally-weighted NASDAQ index over the same two-year time horizon as $P_{2 y r}$, and $I_{2}$ is the value of the equally-weighted NASDAQ index on the second day of trading of the IPO. 
Consistent with Ritter (1991), the average and median long-run performance of all IPOs is negative. Offerings above the offer range have the lowest level of overpricing, but this is not statistically different from all other IPOs. The percent of issues above the offer range that are likely to have negative returns also does not differ from other IPOs.

The cross-sectional relation between the long-run performance $\left(R_{2 y r}\right)$ and the percent change in the offer price from the filing $c f$ the preliminary prospectus to the offer date $\left[P R C H G=\left(P_{\mathrm{O}}-P_{\mathrm{E}}\right) / P_{\mathrm{E}}\right]$ is analyzed in a regression framework, with the following results ( $t$-statistics in parentheses):

$$
\begin{gathered}
R_{2 \mathrm{yr}}=-0.160+0.094 \text { PRCHG, } \quad R^{2}=0.0003, F=0.327, N=1,080 . \\
(-6.05) \quad(0.57)
\end{gathered}
$$

There is a positive but insignificant relation between the revisions in offer price and the degree of overpricing in the long run. A similar though negative relation exists if two-year returns are regressed on initiai returns. Overall, these results do not support the existence of overreaction in issues for which good information is revealed.

\section{Summary}

This paper relates the pre-issue information-gathering activities of underwriters to revisions in offering characteristics and subsequent underpricing. Truthful revelation of good information through demand by regular investors is rewarded by an increase in both share allocation and underpricing. In the model and in practice, the share allocation mechanism is not sufficient to fully compensate investors, since the number of shares to be offered is rationed. Consequently, Benveniste and Srindt predict, and this paper confirms, that underpricing is positively related to revisions in the offer price from the filing of the preliminary prospectus to the offer date. In other words, the final offer price only partially adjusts to new information. The result is that issues that have positive revisions in the offer price and good information revealed are significanily more underpriced than other IPOs.

These findings suggest that underwriters and issuing firms prefer to substitute underpricing for increased allocation. If the issue is rationed, increasing the number of shares issued to meet demand will further dilute the original owners' claim to both the voting rights and cash flows of the firm. Leaving money on the table in the form of higher initial returns, therefore, must have lower value either to the underwriter or to the issuing firm than reducing the size of the owners' residual claims.

An examination of the long-run performance of IPOs by the relation of the final offer price to the preliminary offer range indicates that, unlike short-run 
underpricing, the long-run performance of IPOs is not related to revisions in offer prices.

\section{Ref. zences}

Benveniste, Lawrence M. and Paul A. Spindt, 1989, How investment bankers determine the offer price and allocation of new issues, Journal of Financial Economics 24, 343-361.

Benveniste. Lawrence M. and William J. Wilhelm, 1990, A comparative analysis of IPO proceeds under alternative regulatory environments, Journal of Financial Economics 28, 173-207.

Beatty, Randolph P. and Jay R. Ritter, 1986, Investment banking, reputation, and the underpricing of initial public offerings, Journal of Financial Economics 15, 213-232.

Carter, Richard B. and Steven Manaster, 1990, Initial public offerings and underwriter reputation, Journal of Finance 45, 469-477.

Hanley, Kathleen W. anư Jay R. Ritter, 1992, Going public, in: Peter Newman, Murray Milgate, and John Eatwell, eds., The new Palgrave dictionary of money and finance (Stockton Press, London).

Hanley, Kathleen W. and Wiiiiam J. Wilhelm, 1993, Evidence on the strategic allocation of initial public offerings, Working paper (University of Michigan, Ann Arbor, MI and Boston College, Chestnut Hill, MA).

Ibbotson, Roger G., Jody L. Sindelar, and Jay R. Riiter, 1988, Initial public offerings, Journal of Applied Corporate Finance 1, 37-45.

Megginson, William L. and Kathleen A. W'eiss, 1991, Venture capitalist certification in initial public offerings, Journal of Finance 46, 879-903.

Ritter, Jay R., 1987, The costs of going public, Journal of Financial Economics 19, 269-281.

Ritter, Jay R., 1991, The long-run performance of initial public offerings, Journal of Finance 46, 3-27.

Rock. Kevin, 1986, Why new issues are underpriced, Journal of Financial Economics 15, 187-212.

Smith, Clifford W., 1986, Investment banking and the capital acquisition process, Journal of Financial Economics 15, 3-29.

Sternberg, Theodore D., 1989, Bilateral monopoly and the dynamic properties of initial public offerings, Working paper (Vanderbilt Üniversity, Nashville, TN).

Uttal, Bro, 1986, Inside the deal that made Bill Gates $\$ 350,000,000$, Fortune 114 (July 21), 23-33.

Welch, Ivo, 1991, An empirical examination of models of contract choice in initial public offerings, Journal of Financial and Quantitative Analysis 26, 497-518.

White, Halbert S., 1980, A heteroskedasticity consistent covariance matrix estimator and a direct test of heteroskedasticity, Econometrica 48, 817-838. 